\title{
WIPER APPLICATION OF HERBICIDES TO CALIFORNIAN THISTLE
}

\author{
C. MOYO ${ }^{1}$, K.C. HARRINGTON ${ }^{1}$, P.D. KEMP ${ }^{1}$ and J.P.J. EERENS ${ }^{2}$ \\ ${ }^{1}$ Institute of Natural Resources, Massey University, Palmerston Nth, New Zealand \\ ${ }^{2}$ AgResearch, Ruakura Research Centre, Private Bag 3123, Hamilton, New Zealand
}

Corresponding author: K.Harrington@massey.ac.nz

The effectiveness at recommended rates of triclopyr/picloram (Tordon Gold), clopyralid (Versatill), metsulfuron (Answer) and glyphosate (Roundup GII) for the control of Californian thistle (Cirsium arvense) using a rotary weed wiper (Rotowiper) was tested in a field experiment. The thistles were treated with either single or double passes at the early post-flowering stage. The pasture height was $5-8 \mathrm{~cm}$ and the roller treated all weeds taller than $18 \mathrm{~cm}$. The thistle stem density and botanical composition of the pasture were assessed prior to treatment and throughout a period of 10 months afterwards. All four herbicides were highly effective in reducing the thistle density with over $90 \%$ control for the double pass 8 months after application, and over $80 \%$ control for the single pass, except for triclopyr/picloram with $68 \%$ control. However, 10 months later pasture treated with metsulfuron, clopyralid and picloram/triclopyr still had significantly less clover than before the application. The clover content of glyphosatetreated plots increased significantly 3 months after application, though both glyphosate and metsulfuron caused some short-term grass damage. Possible reasons for the pasture damage are discussed.

\section{CHANGES IN THISTLE POPULATIONS BETWEEN 1984 AND 2006 IN CANTERBURY}

\author{
R. GROENTEMAN ${ }^{1}$, D. KELLY ${ }^{1}$, G.W. BOURDÔT ${ }^{2}$ and S.V. FOWLER ${ }^{3}$ \\ ${ }^{1}$ University of Canterbury, Private Bag 4800, Christchurch, New Zealand \\ ${ }^{2}$ AgResearch Ltd, Gerald Street, PO Box 60, Lincoln, New Zealand \\ ${ }^{3}$ LandCare Research, Gerald Street, PO Box 69, Lincoln, New Zealand
}

Corresponding author: rgr51@student.canterbury.ac.nz.

A survey in 2005-06 to measure the density and ground cover of thistles in the Lincoln district, Canterbury, replicated a method used in 1984-85 and 1985-86, and used the same randomly selected paddocks. The same three thistle species, nodding thistle (Carduus nutans), Californian thistle (Cirsium arvense) and Scotch thistle (Cirsium vulgare), were common in all surveys. During the 2005-06 survey the occurrence of three introduced biocontrol agents was also recorded. It was hypothesised that nodding thistle should have decreased more than the other two species due to it being preferred by two biological control agents released since 1985, Uropohora solstitialis and Trichosirocalus mortadelo (previously $T$. horridus). Despite the biocontrol agents not being restricted solely to nodding thistle, they were not found in paddocks that completely lacked nodding thistle. Although nodding thistle did decrease in cover over the 20 -year period, Scotch thistle decreased proportionately more, making it hard to attribute the changes simply to biological control. Californian thistle increased in density over the 20 -year period but occupied the same percent of ground cover. Land management changes, specifically conversion of high-producing pasture to dairy farming, as found in $42 \%$ of the resurveyed paddocks, may have contributed to species-specific thistle population changes. 